Kebijakan: Jurnal Ilmu Administrasi

Volume 12, Nomor 1, Januari 2021

E-ISSN: 2656-2820

P-ISSN 1829-5762

\title{
ANALISIS IMPLEMENTASI KEBIJAKAN KESEHATAN TERHADAP EFEKTIVITAS ORGANISASI RUMAH SAKIT UMUM DAERAH DALAM MENINGKATKAN PELAYANAN PASIEN RAWAT JALAN DAN INAP ( Studi pada Rumah Sakit Umum Daerah )
}

\author{
Rustandi \\ STIA YPPT Priatin Tasikmalaya \\ Tasikmalaya, Jawa Barat, Indonesia \\ rustandi29011962@gmail.com
}

\begin{abstract}
ABSTRAK
Masalah pelayanan pasien rawat jalan dan inap merupakan masalah yang sangat urgent karena dalam penanganan dan pengelolaannya memerlukan keterampilan kecekatan bahkan biaya peralatan medis yang tinggi. Karena itu pelayanan pasien rawat jalan dan inap di Rumah Sakit Umum Daerah yang lebih efektif merupakan suatu keharusan, Berdasarkan data dari Rumah Sakit Umum Daerah, ternyata pelayanan pasien rawat jalan dan inap masih belum efektif, ini berarti pelayanan pasien rawat jalan dan inap di Rumah Sakit Umum Daerah belum sepenuhnya efektif. Studi ini berujuan untuk mengkaji bagaimana implementasi kebijakan kesehatan dan sejauh mana pengaruhnya terhadap efektifitas organisasi Rumah Sakit Umum Daerah dalam meningkatkan pelayanan pasien rawat jalan dan inap. Dalam penelitian ini menggunakan metode penelitian deskriptif analisis dengan menggunakan pendekatan kuantitatif serta mengacu pada teori implementasi kebijakan yang mempunyai empat komponen yaitu komunikasi, sumber daya, diposisi atau sikap para pelaksana dan struktur birokrasi. Keempat komponen dari teori implementasi kebijakan menjadi pilihan dalam mendampingi penelitian ini, srta sekaligus merupakan sub variabel bebas dari studi ini. Dalam penelitian ini ditentukan populasi dan sampel penelitian ini adalah pegawai pada Rumah Sakit Umum Daerah.. Pengambilan sampel menggunakan proporsional random sampling dengan ukuran sampel 122. Datá primer diperoleh dengan menggunakan angket yang dirancang sesuai dengan keperluan penelitian dan observasi. Data sekunder diperoleh melalui studi dokumentasi. Hasil penelitian ini menunjukkan bahwa implementasi kebijakan kesehatan memberikan pengaruh yang signifikan terhadap efektivitas organisasi umah Sakit Umum Daerah dalam meningkatkan pelayanan pasien rawat jalan dan inap. Di lain pihak faktor disposisi atau sikap para pelaksana memberikan pengaruh yang tidak signifikan terhadap efektivitas organisasi Rumah Sakit Umum Daehrah dalam meningkatkan pelayanan pasien rawat jalan dan inap.
\end{abstract}

Kata Kunci: Implementasi Kebijakan, Efektivitas Organisasi, Pelayanan pasen rawat jalan dan inap.

\begin{abstract}
The problem of outpatient and inpatient services is a very urgent problem because handling and management requires dexterity skills and even high costs of medical equipment. Therefore, more effective outpatient and inpatient services at Regional General Hospitals are a must. General Regions have not been fully effective. This study aims to examine how the implementation of health policies and the extent to which they affect the effectiveness of the Regional General Hospital organization in improving outpatient and inpatient services. This research uses descriptive analysis research method using a quantitative approach and refers to the theory of policy implementation which has four components, namely communication, resources, position or attitude of the implementers and bureaucratic structure. The four components of the policy implementation theory are options in accompanying this research, as well as being the independent sub-variables of this study. In this study, the population was determined and the sample of this study were employees of the Regional General Hospital. The samples were taken using proportional random sampling with a sample size of 122. Primary data were obtained using a questionnaire designed in accordance with the research and observation needs. Secondary data were obtained through documentation study. The results of this study indicate that the implementation of health policies has a significant effect on the organizational effectiveness of the Regional General Hospitals in improving outpatient and inpatient services. On the other hand, the disposition factor or the attitude of the implementers has an insignificant influence on the effectiveness of the Daehrah General Hospital organization in improving outpatient and inpatient services.
\end{abstract}

Key Words: Policy Implementation, Organizational Effectiveness, Outpatient and Inpatient Services. 


\section{Kebijakan: Jurnal Ilmu Administrasi \\ Volume 12, Nomor 1, Januari 2021 \\ E-ISSN: 2656-2820 \\ P-ISSN 1829-5762}

\section{PENDAHULUAN}

Pelayanan kesehatan merupakan pelayanan dasar yang wajib diberikan oleh pemerintah kepada masyarakat dalam rangka meningkatkan kualitas sumber daya manusia, dalam menunjang dan menjaga kelangsungan proses pembangunan yang berperan dan bertanggungjawab untuk melaksanakan dan memelihara kesehatan masyarakat tersebut adalah Rumah Sakit Umum Daerah. Rumah Sakit Umum Daerah sebagai institusi memegang peranan yang sangat strategis dalam rangka meningkatkan derajat kesehatan masyarakat. Oleh karena itu dalam melaksanakan perannya yang strategis ini, rumah sakit perlu dilengkapi dengan berbagai kebijakan yang mengatur bagaimana melindungi rumah sakit sebagai institusi yang memberikan pelayanan kesehatan dan masyarakat sebagai penerima jasa pelayanan kesehatan. Ini berarti keterpaduan dan kontinuitas pelayanan kesehatan yang diberikan oleh rumah sakit kepada masyarakat dapat terjaga.

Rumah Sakit Umum Daerah sebagai ujung tombak dan pelaksana dari berbagai kebijakan yang menyangkut pelayanan kesehatan kepada masyarakat dalam prakteknya selalu mengacu pada kebijakan-kebijakan yang dikeluarkan oleh pemerintah daerah dan kebijakan yang dikeluarkan oleh instansi Rumah Sakit Umum Daerah itu sendiri. Kenyataan yang ada di kedua daerah tersebut menunjukkan bahwa Rumah Sakit Umum Daerah, dapat dikatakan sebagai institusi yang memiliki posisi "non rivalry" sehingga bagi masyarakat merupakan pilihan satu-satunya untuk memperoleh jasa pelayanan kesehatan. Seorang pasien atau keluarga yang berkunjung ke rumah sakit pada dasarnya bertujuan untuk mengobati penyakit yang dideritanya. Mereka datang ke rumah sakit mengharapkan pelayanan kesehatan yang baik dalam arti tidak dibatasi oleh waktu datang, siang atau malam. Datangnya mereka ke rumah sakit bertujuan untuk mengobati penyakit yang sifat penyakitnya itu ringan sehingga pasien itu disebut pasien rawat jalan atau pengobatan yang sifatnya berat dan diperlukan perawatan yang kontinu, pasien ini disebut pasien rawat inap, yang menjadi objek dalam penelitian ini adalah Rumah Sakit Umum Daerah dengan sasarannya adalah pasien rawat inap dengan alasan sebagai berikut; pelayanan terhadap pasien rawat inap relatif lebih lama dan kesan yang dirasakan oleh pasien dalam hal melayaninya lebih dirasakan oleh pasien itu sendiri sehingga ia dapat menilai lebih objektif dalam hal pelayanannya.

Selain itu untuk melayani pasien rawat inap diperlukan berbagai sarana dan prasarana serta fasilitas pelayanan yang kompleks dan unik sesuai dengan kondisi pasien itu sendiri. Pelayanan terhadap pasien rawat inap memiliki peluang untuk menciptakan kemandirian dan lebih profesional dalam hal yang menyangkut kualitas pelayanan. Baik pasien rawat jalan maupun pasien rawat inap pertama kali yang ingin ia temui adalah tenaga kesehatan seperti; dokter, perawat, laboran dan tenaga teknis kesehatan yang bertugas digaris depan (front line). Jadi dengan demikian para pegawai yang melayani langsung kebutuhan pasien yang datang ke rumah sakit berperan sangat menentukan kualitas pelayanan kepada pasien. Pasien kecewa bila orang-orang tidak memperoleh pelayanan yang tidak semestinya. Pihak Rumah Sakit Umum Daerah.

Mengingat bahwa Rumah Sakit Umum Daerah tersebut memegang posisi "Non Rivalry", maka hal ini akan berdampak kepada masyarakat itu sendiri untuk "menerima" layanan jasa kesehatan dengan keadaan mutu apa adanya, karena tidak adanya pilihan lainnya. Keadaan semacam ini tidak bisa dibiarkan bagi Rumah Sakit Umum Daerah tidak ada cara lain selain untuk merespon tuntutan masyarakat akan pelayanan kesehatan yang memadai, dengan cara meningkatkan kualitas pelayanan kesehatan yang berorientasi kepada kepuasan pelanggan atau pasien. Peningkatan kepuasan pelayanan kepada pasien harus dijadikan strategi oleh Rumah Sakit Umum Daerah itu sendiri, sebab akan membawa nama bagi Rumah Sakit Umum Daerah sendiri dan nama Pemerintah Daerah dimana Rumah Sakit Umum Daerah tersebut berada. Berdasarkan hasil penelitian awal, peneliti menemukan berbagai fenomena dari berbagai kejadian, dokumen dan laporan mengenai pelayanan yang diberikan oleh Rumah Sakit Umum Daerah tersebut. Fenomena tersebut digambarkan bahwa Rumah Sakit 


\section{Kebijakan: Jurnal Ilmu Administrasi Volume 12, Nomor 1, Januari 2021 \\ E-ISSN: 2656-2820 \\ P-ISSN 1829-5762}

Umum Daerah pada umumnya dalam menangani calon pasien rawat jaan dan inap belum sesuai dengan standar pelayanan medis yang dituangkan dalam keputusan Direktur Rumah Sakit masingmasing, sehingga kurang mendukung peningkatkan dan penjagaan mutu pelayanan rumah sakit tersebut. Rumah Sakit Umum Daerah dalam melayani calon pasien rawat jalan dan inap ternyata masih belum sesuai standar pelayanan minimal. Dalam standar pelayanan minimal tercantum; tenaga para medik melakukan terapi penderita tetapi kenyataannya penderita masih terjadi padahal penanganan awal mulai dari syarat administratif sampai dengan memberikan obat secepatnya sebab hal ini bagian dari etika medik. Demikian pula aspek pelayanan kesehatan rawat jalan dan inap di Rumah Sakit Umum Daerah pada saat ini, sering terjadi dua lebih pasien di dalam ruang atau kamar periksa dan tidak jarang para anggota keluarga pasien tersebut juga berada di dalam ruang atau kamar periksa.

Gambaran singkat mengenai kualitas pelayanan kesehatan yang diberikan oleh Rumah Sakit Umum Daerah, maka timbul pertanyaan mengapa implementasi kebijakan kesehatan yang dilaksanakan oleh Kedua Rumah Sakit Umum Daerah terhadap efektivitas organisasi Rumah Sakit Umum Daerah dalam rangka meningkatkan pelayanan pasien rawat jalan dan inap belum sesuai dengan apa yang diharapkan. Oleh karena itu diperlukan adanya suatu penelitian yang menyangkut kurang efektifnya implementasi kebijakan kesehatan yang dilakukan oleh kedua rumah sakit umum daerah tersebut. Dalam penelitian ini, peneliti mencoba untuk mencari salah satu / penyebanya yang menyangkut kurang efektifnya implementasi kebijakan kesehatan oleh kedua rumah sakit umum daerah.

Berdasarkan hasil yang diperoleh dari penelitian awal, terlihat adanya berbagai gejala-gejala yang diduga sebagai penyebab kurang efektifnya implementasi kebijakan kesehatan di kedua Rumah Sakit Umum Daerah. Bahwa Keputusan Direktur Rumah Sakit Umum Daerah perihal buku standar minimal pelayanan medis masih belum disosialisasikan secara optimal kepada tenaga medik, para medik dan tenaga front line, padahal upaya tersebut berkaitan dengan peningkatan dan menjaga mutu pelayanan Rumah Sakit Umum Daerah. Masih banyak tenaga medik seperti dokter sebagai pelaksana di Rumah Sakit Umum Daerah yang belum memberikan penjelasan segala sesuatu tentang penyakit yang diderita, tidak hanya didiagnosa, melainkan juga perjalanan penyakit, komplikasi dan kemungkinan kesembuhannya, serta belum banyak menjelaskan pilihan terapi dan resiko serta komplikasi dari masing-masing pilihan. Keadaan tersebut menunjukkan para dokter selaku tenaga medik di Rumah Sakit Umum Daerah masih banyak yang belum memahami petunjuk pelaksanaan, isi kebijakan belum diketahui secara detil, serta kemungkinan sulitnya ada kesamaan pandangan, hal ini berarti penyampaian informasi berkaitan dengan keputusan atau peraturan kode etik kedokteran belum terpadu. Pada Rumah Sakit Umum Daerah masih kurang jumlah sumber daya dilihat dari kualitas dan kuantitas serta berbagai perlengkapan maupun financial yang diperlukan dalam penanganan pasien secara darurat, seperti sumber daya manusia tenaga medik atau dokter dengan jenis keahlian tertentu. Keadaan ini menunjukkan masih kurang perhatiannya terhadap kualitas kerja dan pengembangan karier maupun keterampilan daripada sumber daya manusia pegawai di lingkungan Rumah Sakit Umum Daerah padahal sumber daya manusia sangat menentukan peningkatan derajat dan mutu pelayanan pasien rawat inap. Selanjutnya pada Rumah Sakit Umum Daerah masih sering terjadi lebih dua orang pasien di dalam ruang atau kamar periksa dan tidak jarang para anggota keluarga pasien tersebut juga berada dalam kamar periksa, padahal dalam pemeriksaan itu harus satu orang pasien diperiksa dokter. Hal itu sebagai upaya menyeragamkan sikap dan perilaku bekerja dokter atau tenaga medik untuk menjaga kerahasiahan penyakit yang diderita pasien. Kondisi ini menggambarkan masih belum adanya kesamaan perilaku bekerja atau melayani pasien berobat dalam kamar kerjanya seperti dokter umum dengan dokter gigi, juga tidak cepat melayani pasiennya, dan sulit bertindak cepat dalam menangani pasien berobat. 


\section{METODE}

Desain kuantitaf dan deskriptif survey merupakan desain penelitian yang digunakan peneliti dengan maksud untuk menjelaskan dan menguraikan tingkat keterpengaruhan variabel bebas (independent variabel) terhadap variabel terikat (dependent variabel). Desain kuantittif dan deskriptif survey adalah penelitian dengan cara mengumpulkan informasi dan data dari responden dengan menggunakan angket dari sampel yang mewakili seluruh populasi supaya dilakukan pembuatan generalisasi untuk populasi. Sifat penelitiannya eksplanatory dengan tife kausal karena peneliti akan menggali, mengidentifikasi dan menganalisis besarnya pengaruh implementasi kebijakan kesehatan terhadap efektivitas pelayanan pasien rawat inap di Rumah Sakit Umum Daerah (Suatu Kasus di Rumah Sakit Umum Kota Tasikmalaya dan Banjar), terutama perhatiannya pada sub-sub vaiabel penentu implementasi kebijakan tersebut. Karena sub variabel implementasi kebijakan menjadi pertimbangan digunakannya desain kuantitatif, yang terdiri dari; komunikasi, sumber daya, disposisi, dan struktur birokrasi, berikut dimensinya yang akan diukur dengan menggunakan statistika. Data hasil penelitian diuji sesuai tidakanya dengan hipotesis penelitian yang dirumuskan sebagai jawaban terhadap rumusan masalah, maksud dan tujuan penelitiananya. Keberadaan data peneltian digunakan sebagai ukuran besaran pengaruh dari setiap variabel sehingga dilakukan pengujian kausalitas dari sub-sub variabel dan dimensi-dimensi terhadap variabel terikat. Analisis yang digunakan peneliti yakni analisis regresi linier multipel yang dilanjutkan dengan menggunakan analisis jalur (Part Analysis).

\section{PEMBAHASAN}

Untuk menguji validitas data responden di Rumah Sakit Umum Daerah dapat dilakukan dengan tahapan pada setiap butir maka skor yang ada pada setiap skor yang dimaksud dikorelasikan dengan skor total. Skor butir dipandang sebagai nilai X dan skor total dipandang dengan nilai Y. Dengan diperolehnya indeks validitas setiap butir dapat diketahui dengan pasti butir manakah yang tidak memenuhi syarat ditinjau dari validitasnya. Berdasarkan informasi tersebut peneliti dapat mengganti atau merevisi butir dimaksud. Bagi peneliti yang menginginkan pengujian terhadap butir dapat dilakukan dengan mengkorelasikan butir dengan skor total pada faktor. Butir yang mempunyai korelasi yang positif dengan skor total serta korelasi yang tinggi menunjukan bahwa butir tersebut mempunyai validitas yang tinggi pula, biasanya syarat minimum untuk dianggap memenuhi syarat adalah kalah $r=0,3$. Jadi kalau korelasi butir dengan skor total kurang dari 0,3 maka butir instrumen tersebut tidak valid. (Singarimbun, 1997). Dari hasil perhitungan diketahui bahwa korelasi keempat butir instrumen implementasi kebijakan yang terdiri dari komunikasi $\left(\mathrm{X}_{1}\right)$, sumber daya $\left(\mathrm{X}_{2}\right)$, disposisi $\left(\mathrm{X}_{3}\right)$, dan struktur birokrasi $\left(\mathrm{X}_{4}\right)$.

Tabel 1. Validasi Dimensi Komunikasi $\left(\mathrm{X}_{1}\right)$

\begin{tabular}{|c|c|c|c|c|c|c|c|}
\hline No & $\mathbf{R}_{\text {hitung }}$ & $\mathbf{R}_{\text {kritis }}$ & Keterangan & No & $\mathbf{R}_{\text {hitung }}$ & $\mathbf{R}_{\text {kritis }}$ & Keterangan \\
\hline 1 & 0,370 & 0,3 & Valid & 7 & 0,301 & 0,3 & Valid \\
\hline 2 & 0,357 & 0,3 & Valid & 8 & 0,391 & 0,3 & Valid \\
\hline 3 & 0,387 & 0,3 & Valid & 9 & 0,491 & 0,3 & Valid \\
\hline 4 & 0,493 & 0,3 & Valid & 10 & 0,420 & 0,3 & Valid \\
\hline 5 & 0,393 & 0,3 & Valid & 11 & 0,376 & 0,3 & Valid \\
\hline 6 & 0,327 & 0,3 & Valid & 12 & 0,327 & 0,3 & Valid \\
\hline
\end{tabular}

Sumber: Hasil Data Olahan, 2019.

Dari tabel di atas diketahui semua instrumen valid untuk sub variabel komunikasi, karena nilai $r$ korelasinya lebih besar dari nilai kritis $=0,3$, maka semua item adalah valid. Hal ini seperti diuraikan berikut ini ; 
Kebijakan: Jurnal Ilmu Administrasi

Volume 12, Nomor 1, Januari 2021

E-ISSN: 2656-2820

P-ISSN 1829-5762

a) Nilai item pertanyaan nomor 1(mengirimkan informasi tugas pekerjaan yang rinci), item pertanyaan nomor 2 (menyampaikan instruksi secara cermat pada pelaksana), item pertanyaan nomor 3 (membagikan tugas pelaksana secara jelas), dan item pertanyaan nomor 4 (seluruh isi informasi dipahami pelaksana), ini berarti seluruh item pertanyaan daripada dimensi transmisi telah memiliki keandalan.

b) Nilai item pertanyaan nomor 1 (menyebarluaskan petunjuk teknis yang akurat), item pertanyaan nomor 2 (instruksi menyusun tugas pekerjaan secara jelas), item pertanyaan nomor 3 (melakukan tindakan sesuai aturan), dan item pertanyaan nomor 4 (mentaati aturan secara terus menerus), ini berarti seluruh item pertanyaan daripada dimensi kejelasan item memiliki keandalan.

c) Nilai item pertanyaan nomor 1 (menyelaraskan tugas dan pekerjaan yang baik), item pertanyaan nomor 2 (memberi perintah konsisten pada tugas), item pertanyaan nomor 3 (menyampaikan perintah, tugas dan pekerjaan secara jelas), dan item pertanyaan nomor 4 (isi berita secara keseluruhan tidak membingungkan), ini berarti seluruh item pertanyaan daripada dimensi konsistensi telah memiliki keandalan.

Dari hasil perhitungan diketahui bahwa korelasi butir instrumen sub variabel sumber daya $\left(\mathrm{X}_{2}\right)$ daripada implemetnasi kebijakan kesehatan digambarkan pada tabel berikut ini.

Tabel 2. Validasi Dimensi Sumber Daya $\left(\mathrm{X}_{2}\right)$

\begin{tabular}{|c|c|c|c|c|c|c|c|}
\hline No & $\mathbf{R}_{\text {hitung }}$ & $\mathbf{R}_{\text {kritis }}$ & Keterangan & No & $\mathbf{R}_{\text {hitung }}$ & $\mathbf{R}_{\text {kritis }}$ & Keterangan \\
\hline 1 & 0,335 & 0,3 & Valid & 11 & 0,423 & 0,3 & Valid \\
\hline 2 & 0,353 & 0,3 & JUValid & 12 & 0,439 & 0,31 S & Ll a Valid \\
\hline 3 & 0,380 & 0,3 & Valid & 13 & 0,307 & 0,3 & Valid \\
\hline 4 & 0,492 & 0,3 & Valid & 14 & 0,313 & 0,3 & Valid \\
\hline 5 & 0,489 & 0,3 & Valid & 15 & 0,392 & 0,3 & Valid \\
\hline 6 & 0,357 & 0,3 & Valid & 16 & 0,521 & 0,3 & Valid \\
\hline 7 & 0,433 & 0,3 & Valid & 17 & 0,486 & 0,3 & Valid \\
\hline 8 & 0,369 & 0,3 & Valid & 18 & 0,432 & 0,3 & Valid \\
\hline 9 & 0,396 & 0,3 & Valid & 19 & 0,381 & 0,3 & Valid \\
\hline 10 & 0,393 & 0,3 & Valid & 20 & 0,398 & 0,3 & Valid \\
\hline
\end{tabular}

Sumber: Hasil Data Olahan, 2019.

Dari tabel di atas diketahui semua instrumen valid untuk sub variabel sumber daya, karena nilai r korelasinya lebih besar dari nilai kritis $=0,3$, maka semua item adalah valid. Hal ini seperti diuraikan berikut ini ;

a) Nilai item pertanyaan nomor 1 (jumlah pelaksana yang tepat), item pertanyaan nomor 2 (pelaksana memiliki keahlian bekerja), item pertanyaan nomor 3 (menunjukkan hasil kerja yang baik), item pertanyaan nomor 4 (trampil menyelesain pekerjaan), dan item pertanyaan nomor 5 (cepat melaporkan hasil kerjanya), ini berarti seluruh item pertanyaan daripada dimensi staf telah memiliki keandalan.

b) Nilai item pertanyaan nomor 1 (mampu menyesuaikan dalam melaksanakan tugs), item pertanyaan nomor 2 (mekanisme pekerjaan memadai), item pertanyaan nomor 3 (memenuhi kebutuhan pekerjaan), item pertanyaan nomor 4 (membagi pekerjaan dengan secara cermat), dan item pertnyaan nomor 5 (mengatur jadwal sesuai beban kerjanya), ini berarti seluruh item pertanyaan daripada dimensi informasi item memiliki keandalan. 
c) Nilai item pertanyaan nomor 1 (meyakinkan pekerjaan), item pertanyaan nomor 2 (menjelaskan isi pekerjaan), item pertanyaan nomor 3 (mengatur wewenang secara jelas), item pertanyaan nomor 4 (wewenang pelaksana sesuai tnggungjawabnya), dan item pertanyaan nomor 5 (wewenang mengarahkan pelksana dalam bekerja), ini berarti seluruh item pertanyaan daripada dimensi wewenang telah memiliki keandalan.

d) Nilai item pertanyaan nomor 1 (prasarana kerja lengkap bagi pelaksana), item pertanyaan nomor 2 (pelaksana mengerti apa yang harus dilakukan), item pertanyaan nomor 3 (menggunakan prasarana dalam bekerja), item pertanyaan nomor 4 (semua prasarana mendukung pekerjaan), dan item pertanyaan nomor 5 (fasilitas pekerjaan disediakan pimpinan), ini berarti seluruh item pertanyaan daripada dimensi fasilitas telah memiliki keandalan.

Dari hasil perhitungan diketahui bahwa korelasi butir instrumen sub variabel disposisi atau sikap pelaksana $\left(\mathrm{X}_{3}\right)$ daripada implementasi kebijakan kesehatan digambarkan pada tabel berikut ini.

Tabel 3. Validasi Dimensi Disposisi $\left(\mathrm{X}_{3}\right)$

\begin{tabular}{|c|c|c|c|c|c|c|c|}
\hline No & $\mathbf{R}_{\text {hitung }}$ & $\mathbf{R}_{\text {kritis }}$ & Keterangan & No & $\mathbf{R}_{\text {hitung }}$ & $\mathbf{R}_{\text {kritis }}$ & Keterangan \\
\hline 1 & 0,378 & 0,3 & Valid & 8 & 0,316 & 0,3 & Valid \\
\hline 2 & 0,414 & 0,3 & Valid & 9 & 0,328 & 0,3 & Valid \\
\hline 3 & 0,339 & 0,3 & Valid & 10 & 0,476 & 0,3 & Valid \\
\hline 4 & 0,338 & 0,3 & Valid & 11 & 0,375 & 0,3 & Valid \\
\hline 5 & 0,321 & 0,3 & Valid & 12 & 0,318 & 0,3 & Valid \\
\hline 6 & 0,325 & 0,3 & Valid & 13 & 0,378 & 0,3 & Valid \\
\hline 7 & 0,395 & 0,3 & Valid & & & & \\
\hline
\end{tabular}

Sumber: Hasil Data Olahan, 2019.

Dari tabel di atas diketahui semua instrumen valid untuk sub variabel disposisi atau sikap pelaksana, karena nilai $r$ korelasinya lebih besar dari nilai kritis $=0,3$, maka semua item adalah valid atau andal. Hal ini seperti diuraikan berikut ini;

a) Nilai item pertanyaan nomor 1 (melaksanakan perintah atasan), item pertanyaan nomor 2 (menerapkan aturan yang sudah baku), item pertanyaan nomor 3 (pelaksana berdedikasi tinggi), item pertanyaan nomor 4 (pelaksana trampil menyelesain pekerjaan), item pertanyaan nomor 5 (menerapkan kriteria pelaksana), item pertanyaan nomor 6 (memperhaikan pengalaman kerja pelaksana), dan item pertanyaan nomor 7 (pelaksana menyerahkan setiap kebutuhan pekerjaan), ini berarti seluruh item pertanyaan daripada dimensi pengangkatan birokrasi telah memiliki keandalan.

b) Nilai item pertanyaan nomor 1 (menambah biaya tertentu pada pelaksana), item pertanyaan nomor 2 (menambah biaya uang lembur untuk pelaksana), item pertanyaan nomor 3 (mengeluarkan biaya tambahan sesuai benan kerjanya), item pertanyaan nomor 4 (memenuhi kepentingan pribadi pelaksana), item pertanyaan nomor 5 (memenuhi kepentingan organisasi), dan item pertanyaan nomor 6 (menerapkan aturan insentif), ini berarti seluruh item pertanyaan daripada dimensi insentif item memiliki keandalan.

Dari hasil perhitungan diketahui bahwa korelasi butir instrumen sub variabel struktur birorkasi $\left(\mathrm{X}_{4}\right)$ daripada implementasi kebijakan kesehatan digambarkan pada tabel berikut ini.

Tabel 4. Validasi Dimensi Struktur Birokrasi $\left(\mathrm{X}_{4}\right)$

\begin{tabular}{|c|c|c|c|c|c|c|c|}
\hline No & $\mathbf{R}_{\text {hitung }}$ & $\mathbf{R}_{\text {kritis }}$ & Keterangan & No & $\mathbf{R}_{\text {hitung }}$ & $\mathbf{R}_{\text {kritis }}$ & Keterangan \\
\hline 1 & 0,751 & 0,3 & Valid & 6 & 0,777 & 0,3 & Valid \\
\hline 2 & 0,812 & 0,3 & Valid & 7 & 0,787 & 0,3 & Valid \\
\hline 3 & 0,814 & 0,3 & Valid & 8 & 0,726 & 0,3 & Valid \\
\hline
\end{tabular}


Kebijakan: Jurnal Ilmu Administrasi

Volume 12, Nomor 1, Januari 2021

E-ISSN: 2656-2820

P-ISSN 1829-5762

\begin{tabular}{|c|c|c|c|c|c|c|c|}
\hline 4 & 0,803 & 0,3 & Valid & 9 & 0,813 & 0,3 & Valid \\
\hline 5 & 0,809 & 0,3 & Valid & 10 & 0,751 & 0,3 & Valid \\
\hline
\end{tabular}

Sumber: Hasil Data Olahan, 2019.

Dari tabel di atas diketahui semua instrumen valid untuk sub variabel struktur birokrasi, karena nilai $r$ korelasinya lebih besar dari nilai kritis $=0,3$, maka semua item adalah valid atau andal. Hal ini seperti diuraikan berikut ini ;

a) Nilai item pertanyaan nomor 1 (melaksanakan tugas sesuai aturan), item pertanyaan nomor 2 (bekerja menurut standar), item pertanyaan nomor 3 (menunjukkan hasil kerjanya), item pertanyaan nomor 4 (bekerja penuh tanggungjawab), item pertanyaan nomor 5 (merinci tugas pekerjaan), ini berarti seluruh item pertanyaan daripada dimensi melaksanakan sistem operasional prosedure telah memiliki keandalan.

b) Nilai item pertanyaan nomor 1 (menyebarkan tugas pelaksana), item pertanyaan nomor 2 (mengatur aktivitas pekerjaan), item pertanyaan nomor 3 (mengatur hubungan unit kerja), item pertanyaan nomor 4 (menjelaskan tanggung jawab unit kerja), dan item pertanyaan nomor 5 (memelihara kerjasama antar unit kerja), ini berarti seluruh item pertanyaan daripada dimensi pelaksananan pragmentasi telah memiliki keandalan.

Selanjutnya instrumen penelitian efektivitas organisasi Rumah Sakit Umum Daerah dalam meningkatkan pelayanan pasien rawat jalan dan inap mencakup dimensi kesiapan dan perolehan sumber daya $\left(\mathrm{Y}_{1}\right)$, dimensi hubungan antar manusia $\left(\mathrm{Y}_{2}\right)$, dimensi proses internal dan tujuan rasional $\left(\mathrm{Y}_{3}\right)$, dan dimensi sistem terbuka $\left(\mathrm{Y}_{4}\right)$.

Tabel 5. Validasi Dimensi Kesiapan dan Perolahan Sumber Daya $\left(\mathrm{Y}_{1}\right)$

\begin{tabular}{|c|c|c|c|c|c|c|c|}
\hline No & $\mathbf{R}_{\text {hitung }}$ & $\mathbf{R}_{\text {kritis }}$ & Keterangan & No & $\mathbf{R}_{\text {hitung }}$ & $\mathbf{R}_{\text {kritis }}$ & Keterangan \\
\hline 1 & 0,753 & 0,3 & Ul. Valid & 6 & 0,681 & 0,3 & 1 Valid \\
\hline 2 & 0,749 & 0,3 & Valid & 7 & 0,697 & 0,3 & Valid \\
\hline 3 & 0,690 & 0,3 & Valid & 8 & 0,710 & 0,3 & Valid \\
\hline 4 & 0,741 & 0,3 & Valid & 9 & 0,679 & 0,3 & Valid \\
\hline 5 & 0,616 & 0,3 & Valid & 10 & 0,626 & 0,3 & Valid \\
\hline
\end{tabular}

Sumber: Hasil Data Olahan, 2019.

Dari tabel di atas diketahui semua instrumen valid untuk dimensi kesiapan dn perolehn sumber daya (Y1), karena nilai $r$ korelasinya lebih besar dari nilai kritis $=0,3$, maka semua item adalah valid atau andal. Dari hasil perhitungan diketahui bahwa korelasi butir instrumen dimensi kriteri hubungan antar manusia $\left(\mathrm{Y}_{2}\right)$ daripada efektivitas pelayanan pasien rawat inap digambarkan pada tabel berikut ini.

Tabel 6. Validasi Dimensi Hubungan Antar Manusia $\left(\mathrm{Y}_{2}\right)$

\begin{tabular}{|c|c|c|c|c|c|c|c|}
\hline No & $\mathbf{R}_{\text {hitung }}$ & $\mathbf{R}_{\text {kriti }}$ & Keterangan & No & $\mathbf{R}_{\text {hitung }}$ & $\mathbf{R}_{\text {kritis }}$ & Keterangan \\
\hline 1 & 0,677 & 0,3 & Valid & 8 & 0,758 & 0,3 & Valid \\
\hline 2 & 0,784 & 0,3 & Valid & 9 & 0,687 & 0,3 & Valid \\
\hline 3 & 0,752 & 0,3 & Valid & 10 & 0,734 & 0,3 & Valid \\
\hline 4 & 0,704 & 0,3 & Valid & 11 & 0,705 & 0,3 & Valid \\
\hline 5 & 0,798 & 0,3 & Valid & 12 & 0,702 & 0,3 & Valid \\
\hline 6 & 0,754 & 0,3 & Valid & 13 & 0,709 & 0,3 & Valid \\
\hline 7 & 0,753 & 0,3 & Valid & & & & \\
\hline
\end{tabular}

Sumber: Hasil Data Olahan, 2019.

Dari tabel di atas diketahui semua instrumen valid untuk dimensi hubungan antar manusia (Y2), karena nilai $r$ korelasinya lebih besar dari nilai kritis $=0,3$, maka semua item adalah valid atau andal. Dari hasil perhitungan diketahui bahwa korelasi butir instrumen dimensi kriteria proses internal dan 
Kebijakan: Jurnal Ilmu Administrasi

Volume 12, Nomor 1, Januari 2021

E-ISSN: 2656-2820

P-ISSN 1829-5762

tujuan rasional $\left(\mathrm{Y}_{3}\right)$ daripada efektivitas pelayanan pasien rawat inap digambarkan pada tabel berikut ini.

Tabel 7. Validasi Dimensi Proses Internal dan Tujuan Rasional $\left(\mathrm{Y}_{3}\right)$

\begin{tabular}{|c|c|c|c|c|c|c|c|}
\hline No & $\mathbf{R}_{\text {hitung }}$ & $\mathbf{R}_{\text {kritis }}$ & Keterangan & No & $\mathbf{R}_{\text {hitung }}$ & $\mathbf{R}_{\text {kritis }}$ & Keterangan \\
\hline 1 & 0,725 & 0,3 & Valid & 9 & 0,785 & 0,3 & Valid \\
\hline 2 & 0,715 & 0,3 & Valid & 10 & 0,736 & 0,3 & Valid \\
\hline 3 & 0,709 & 0,3 & Valid & 11 & 0,645 & 0,3 & Valid \\
\hline 4 & 0,789 & 0,3 & Valid & 12 & 0,726 & 0,3 & Valid \\
\hline 5 & 0,717 & 0,3 & Valid & 13 & 0,721 & 0,3 & Valid \\
\hline 6 & 0,672 & 0,3 & Valid & 14 & 0,679 & 0,3 & Valid \\
\hline 7 & 0,783 & 0,3 & Valid & 15 & 0,759 & 0,3 & Valid \\
\hline 8 & 0,782 & 0,3 & Valid & 16 & 0,777 & 0,3 & Valid \\
\hline
\end{tabular}

Sumber: Hasil Data Olahan, 2019.

Dari tabel di atas diketahui semua instrumen valid untuk dimensi kriteria proses inernal dan tujuan rasional (Y3), karena nilai $\mathrm{r}$ korelasinya lebih besar dari nilai kritis $=0,3$, maka semua item adalah valid atau andal. Dari hasil perhitungan diketahui bahwa korelasi butir instrumen dimensi kriteria sistem terbuka $\left(\mathrm{Y}_{4}\right)$ daripada efektivitas pelayanan pasien rawat inap digambarkan pada tabel berikut ini.

Tabel 8. Validasi Dimensi Kriteria Sistem Terbuka $\left(\mathrm{Y}_{4}\right)$

\begin{tabular}{|c|c|c|c|c|c|c|c|}
\hline No & $\mathbf{R}_{\text {hitung }}$ & $\mathbf{R}_{\text {kritis }}$ & Keterangan & $\mathbf{N o}$ & $\mathbf{R}_{\text {hitung }}$ & $\mathbf{R}_{\text {kritis }}$ & Keterangan \\
\hline 1 & 0,753 & 0,3 & Valid & 7 & 0,605 & 0,3 & Valid \\
\hline 2 & 0,756 & 0,3 & Valid & 8 & 0,630 & 0,3 & Valid \\
\hline 3 & 0,674 & 0,3 & Valid & 9 & 0,687 & 0,3 & Valid \\
\hline 4 & 0,752 & 0,3 & Valid & 10 & 0,678 & 0,3 & Valid \\
\hline 5 & 0,812 & 0,3 & Valid & 11 & 0,744 & 0,3 & \multirow{2}{*}{ Valid } \\
\hline 6 & 0,703 & 0,3 & Valid & & & & \\
\hline
\end{tabular}

Sumber: Hasil Data Olahan, 2019.

Dari tabel di atas diketahui semua instrumen valid untuk dimensi kriteria sistem terbuka $\left(\mathrm{Y}_{4}\right)$, karena nilai $\mathrm{r}$ korelasinya lebih besar dari nilai kritis $=0,3$, maka semua item adalah valid atau andal. Dari hasil penelitian (hasil perhitungan) menunjukkan telah diperoleh nilai koefisien korelasi antara dimensi-dimensi implementasi kebijakan (X) meliputi komunikasi $\left(\mathrm{X}_{1}\right)$, sumber daya $\left(\mathrm{X}_{2}\right)$, Disposisi (x3) dan Struktur Birokrasi $\left(\mathrm{X}_{4}\right)$ terhadap efektivitas organisasi rumah sakit umm daerah dalam meningkatkan pelayanan pasien rawat jalan dan inap (Y) seperti berikut ini.

Nilai koefisien korelasi antara dimensi komunikasi $\left(\mathrm{X}_{1}\right)$ dengan terhadap efektivitas organisasi rumah sakit umm daerah dalam meningkatkan pelayanan pasien rawat jalan dan inap (Y) sebesar $\mathrm{r}=$ 0,725, ini berarti terdapat hubungan yang cukup kuat antara dimensi komunikasi dengan terhadap efektivitas organisasi rumah sakit umm daerah dalam meningkatkan pelayanan pasien rawat jalan dan inap (Y). Hubungannya kuat dibuktikan karena nilai $\mathrm{r}$ korelasinya lebih besar dari 0 , berarti terjadi hubungan yang linier positif, diindikasikan semakin besar nilai dimensi komunikasi maka semakin besar efektivitas pelayanan pasien rawat inap. Dalam pelaksanaan dimensi komunikasi yang dicirikan oleh kemampuan menerapkan aspek transmisi, konsistensi dan kejelasan sehingga ketiganya membantu para pejebat pelaksana yang melaksanakan kebijakan kesehatan terutama.

Nilai koefisien korelasi antara dimensi sumber daya $\left(\mathrm{X}_{2}\right)$ dengan efektivitas organisasi rumah sakit umm daerah dalam meningkatkan pelayanan pasien rawat jalan dan inap sebesar $r=0,751$, ini berarti terdapat hubungan yang cukup kuat antara dimensi sumber daya dengan efektivitas organisasi rumah sakit umm daerah dalam meningkatkan pelayanan pasien rawat jalan dan inap. Hubungannya 


\section{Kebijakan: Jurnal Ilmu Administrasi Volume 12, Nomor 1, Januari 2021 \\ E-ISSN: 2656-2820 \\ P-ISSN 1829-5762}

ini karena nilai korelasinya lebih dari 0, terjadi hubungan yang linier positif artinya semakin besar nilai dimensi sumber daya maka semakin besar nilai efektivitas organisasi rumah sakit umm daerah dalam meningkatkan pelayanan pasien rawat jalan dan inap. Dalam pembinaan sumber daya mencakup aspek sumber daya manusia pegawai tenaga kesehatan atau staf, informasi atau keterangan yang berkaitan dengan pekerjaannya, wewenang yang merupakan legitimasi dari para pelaksana kebijakan, serta fasilitas lain yang mendukung pelaksanaan kebijakan di rumah sakit umum seperti peningkatan sarana dan prasarana kesehatan, peningkatan pelayanan administrasi rumah sakit.

Nilai koefisien korelasi antara dimensi disposisi $\left(\mathrm{X}_{3}\right)$ dengan efektivitas organisasi rumah sakit umm daerah dalam meningkatkan pelayanan pasien rawat jalan dan inap sebesar $r=0,580$, ini berarti terdapat hubungan yang rendah antara dimensi disposisi atau sikap para pejabat pelaksana dengan efektivitas organisasi rumah sakit umm daerah dalam meningkatkan pelayanan pasien rawat jalan dan inap. Rendahnya hubungan dibuktikan karena nilai $r$ korelasinya sama dengan 0 , berarti hubungan kurang linier, diindikasikan semakin kecil nilai dimensi disposisi atau sikap para pejabat pelaksana maka semakin kecil pula efektivitas organisasi rumah sakit umm daerah dalam meningkatkan pelayanan pasien rawat jalan dan inap. Sikap atau disposisi para pejabat pelaksana kebijakan kesehatan dinilai rendah korelasinya dengan efektivitas organisasi rumah sakit umm daerah dalam meningkatkan pelayanan pasien rawat jalan dan inap, artinya sikap dan komitmen para pejabat pelaksana yang masih rendah dalam melaksanakan kebijakan kesehatan, para pejabat pelaksana masih belum secara keseluruhan mengetahui apa yang harus dikerjakannya, serta pra pejabat pelaksana masih belum memperhatikan kepentingan keorgnisasian maupun personel dalam melaksanakan kebijakan kesehatan terhadap efektivitas organisasi rumah sakit umm daerah dalam meningkatkan pelayanan pasien rawat jalan dan inap.

Nilai koefisien korelasi antara dimensi struktur birokrasi $\left(\mathrm{X}_{4}\right)$ dengan efektivitas organisasi rumah sakit umm daerah dalam meningkatkan pelayanan pasien rawat jalan dan inap sebesar $\mathrm{r}=$ 0,608 , ini berarti terdapat hubungan yang cukup kuat antara dimensi struktur birokrasi dengan efektivitas organisasi rumah sakit umm daerah dalam meningkatkan pelayanan pasien rawat jalan dan inap. Hubungannya kuat dibuktikan karena nilai $r$ korelasinya lebih besar dari 0 , berarti terjadi hubungan yang linier positif, diindikasikan semakin besar nilai dimensi struktur birokrasi maka semakin besar efektivitas organisasi rumah sakit umm daerah dalam meningkatkan pelayanan pasien rawat jalan dan inap. Pelaksanaan struktur birokrasi efektivitas organisasi rumah sakit umm daerah dalam meningkatkan pelayanan pasien rawat jalan dan inap dikembangkan melalui pemberlakuan sistem operasional prosedure yang ada pada setiap unit atau bidang di rumah sakit umum daerah.

Pengaruh secara langsung sub variabel komunikasi terhadap efektivitas organisasi rumah sakit umm daerah dalam meningkatkan pelayanan pasien rawat jalan dan inap sebesar $12,88 \%$, artinya aspek komunikasi melalui transisi, konsisten, dan kejelasan sangat membantu para pejabat pelaksana yang melaksanakan kebijakan kesehatan dalam rangka meningkatkan efektivitas organisasi rumah sakit umm daerah dalam meningkatkan pelayanan pasien rawat jalan dan inap. Upaya mengelola transmisi, konsistensi, dan kejelasan di dalam melaksanakan komunikasi oleh para pejabat pelaksana yang melaksanakan kebijakan kesehatan dinilai cukup baik, ini ditandai dengan peningkatan keleluasaan para pejabat pelaksana menyampaikan pesan berkaitan dengan pelayanan kesehatan khususnya pelayanan pasien rawat inap. Para pejabat pelaksana yang melaksanakan kebijakan kesehatan mengetahui kebijakan yang harus dikerjakan Rumah Sakit Umum Daerah antara lain; perluasan dan penambahan tempat tidur pasien, dibangunnya IBD representatif, upayakan penambahan peralatan medis dan penunjang medis menuju standar maksimal 2018, sistim pengelolaan pegawai rumah sakit yang efektif dan efisien termasuk dalam peningkatan kesejahteraannya, dan mewujudkan kemampuan dalam peralatan organisasi rumah sakit. 


\section{Kebijakan: Jurnal Ilmu Administrasi \\ Volume 12, Nomor 1, Januari 2021 \\ E-ISSN: 2656-2820 \\ P-ISSN 1829-5762}

Pengaruh secara langsung sub variabel sumber daya terhadap efektivitas organisasi rumah sakit umm daerah dalam meningkatkan pelayanan pasien rawat jalan dan inap sebesar 15,92\%. Pernyataan tersebut mengandung arti bahwa para pejabat pelaksana yang melaksanakan kebijakan kesehatan mulai dari Direktur, Wakil Direktur Pelayanan, Wakil Direktur Umum dan Keuangan, Komite Medik, Komite Keperawatan, Kepala Bagian dan Sub Bagian di Rumah Sakit Umum Daerah dinilai mencukupi sesuai dengan keahlian dan kemampuannya karena setiap periode seluruh jajaran pejabat strukural, staf di komite maupun para kepala bagian diberikan kesempatan untuk mengikuti diklatpim, diklat keahlian medik, seminar yang berkaitan dengan profesi kesehatan dan kedokteran. Pengaruh secara langsung sub variabel disposisi atau sikap pelaksana terhadap efektivitas organisasi rumah sakit umm daerah dalam meningkatkan pelayanan pasien rawat jalan dan inap sebesar $1,12 \%$. Pernyataan tersebut menunjukkan sikap dan komitmen dari para pejabat pelaksana yang melaksanakan kebijakan kesehatan masih rendah terhadap efektivitas organisasi rumah sakit umm daerah dalam meningkatkan pelayanan pasien rawat jalan dan inap. Hal ini ditandai dengan masih adanya sikap yang tidak kompak atau adanya pilih kasih daripada para pejabat pelaksana terutama di dalam menjelaskan perihal pemilihan orang-orang yang punya dedikasi bekerja dan mendahulukan kepentingan umum serta masih belum sepenuhnya memperhatikan insnetif di Rumah Sakit Umum Daerah.

Pengaruh secara langsung sub variabel struktur birokrasi terhadap efektivitas organisasi rumah sakit umm daerah dalam meningkatkan pelayanan pasien rawat jalan dan inap sebesar 2,85\%. Pernyataan tersebut menunjukkan para pejabat pelaksana yang melaksanakan kebijakan kesehatan telah menerapkan prosedure kerja serta standar pekerjaan yang dilaksanakan terutama dalam program kebijakan kesehatan dan efektivitas pelayanan pasien rawat inap di Rumah Sakit Umum Daerah. Berdasarkan hasil penelitian pengaruh implementsi kebijakan kesehatan melalui faktor komunikasi, sumber daya, disposisi atau sikap pelaksana dan struktur birokrasi terhadap efektivitas organisasi rumah sakit umm daerah dalam meningkatkan pelayanan pasien rawat jalan dan inap hanya sebesar $58,10 \%$. Artinya terdapat faktor lain yang tidak diteliti seperti faktor kesepakatan dan kemampuan kepemimpinan, serta faktor di luar rumah sakit seperti lingkungan ekonomi, lingkungan sosial dan lainnya, tetapi berpengaruh terhadap efektivitas organisasi rumah sakit umm daerah dalam meningkatkan pelayanan pasien rawat jalan dan inap sebesar 41,90\%. Demikian pula hasil penelitian pengaruh implementsi kebijakan kesehatan melalui faktor komunikasi, sumber daya, disposisi atau sikap pelaksana dan struktur birokrasi terhadap efektivitas organisasi rumah sakit umm daerah dalam meningkatkan pelayanan pasien rawat jalan dan inap sebesar 72,00\%. Artinya terdapat faktor lain yang tidak diteliti seperti; faktor kesepakatan dan kemampuan kepemimpinan, serta faktor di luar rumah sakit seperti lingkungan ekonomi, lingkungan sosial dan lainnya, tetapi berpengaruh terhadap efektivitas organisasi rumah sakit umm daerah dalam meningkatkan pelayanan pasien rawat jalan dan inap sebesar $28,00 \%$.

\section{SIMPULAN}

Implementasi kebijakan kesehatan, ternyata faktor komunikasi, sumber daya, disposisi atau sikap pelaksana, struktur birokrasi secara bersama-sama berpengaruh secara signifikan terhadap efektivitas organisasi rumah sakit umm daerah dalam meningkatkan pelayanan pasien rawat jalan dan inap artinya secara simultan faktor komunikasi, sumber daya, disposisi atau sikap pelaksana dan struktur birokrasi memberikan kontribusi terhadap efektivitas organisasi rumah sakit umm daerah dalam meningkatkan pelayanan pasien rawat jalan dan inap. Faktor komunikasi berpengaruh secara signifikan terhadap efektivitas organisasi rumah sakit umm daerah dalam meningkatkan pelayanan pasien rawat jalan dan inap artinya faktor komunikasi memberikan kontribusi yang cukup besar. Faktor sumber daya berpengaruh secara signifikan terhadap efektivitas organisasi rumah sakit umm 


\section{Kebijakan: Jurnal Ilmu Administrasi \\ Volume 12, Nomor 1, Januari 2021 \\ E-ISSN: 2656-2820 \\ P-ISSN 1829-5762}

daerah dalam meningkatkan pelayanan pasien rawat jalan dan inap artinya faktor sumber daya memberikan kontribusi yang cukup besar terhadap efektivitas organisasi rumah sakit umm daerah dalam meningkatkan pelayanan pasien rawat jalan dan inap. Faktor struktur birokrasi berpengaruh secara signifikan terhadap efektivitas organisasi rumah sakit umm daerah dalam meningkatkan pelayanan pasien rawat jalan dan inap artinya faktor struktur birokrasi memberikan kontribusi yang cukup besar terhadap efektivitas organisasi rumah sakit umm daerah dalam meningkatkan pelayanan pasien rawat jalan dan inap. Selanjutnya faktor disposisi atau sikap para pelaksana berpengaruh secara tidak signifikan terhadap efektivitas organisasi rumah sakit umm daerah dalam meningkatkan pelayanan pasien rawat jalan dan inap artinya faktor disposisi atau sikap para pelaksana memberikan kontribusi yang kecil terhadap efektivitas pelayanan pasien rawat inap di Rumah Sakit Umum. Dengan demikian terjadinya perbedaan secara keseluruhan pada implementasi kebijakan kesehatan lebih disebabkan oleh adanya perbedaan yang berarti pada kondisi disposisi dari kedua rumah sakit tersebut, dibandingkan dengan komunikasi sumber daya maupun struktur birokrasi yang ada pada masing-masing rumah sakit tersebut.

\section{DAFTAR PUSTAKA}

Aditama.Yoga.Tjandra, 2000. Manajemen Administrasi Rumah Sakit. Jakarta. Universitas Indonesia; Adikusumo, Suparto, Manajemen Rumah Sakit, Jakarta. Sinar harapan;

Agustino. Leo, 2006. Dasar-dasar kebijakan Publik, Bandung. Alfabeta;

Djamin, Awaludin, 1994. Penyempurnaan Aparatur dan Administrasi Negara Republik Indonesia. Jakarta. Yayasan Pembina Manajemen LAN RI ;

Dojodiprojo, Darmnto, Kiat mengelola Rumah Sakit. Jakarta. Hipokreates;

Dresang, L, Dennis, 2001. Public Personnel Managemnt and Public Policy; Hongkong. Toronto;

Edwar III. George C, 1980. Implementing Public Policy. Woshington. D.C. Congressional Queterly.

Farnham, David and Horton, Siltia, 1993. Managing Thed New Publoic Service. Hongkong. Macmillan;

Foremont Kast \& James Rosenweight, 1979. Organization and Manajemen A System Contingensi dan Approach. Amerika Serikat. Mc Graw Hill.

Frederickson. George, 1987. New public Administration. Alabama. The University Of Alabana Press; Grindle, Merilee \& Thomas, W. John, 1980. Public Choices and Policy Change. London. The Jones Hopkins University Press;

Goggin, Malcon, 1990. Implementation Theory and Practice. London. Foresman and Company;

Kartiwa, Asep, 2004. Membangun Birokrasi Pemerintah Daerah Yang Profesional Menuju Terwujudnya Good Governance. Bandung. Pascasarjana Universitas Padjadjaran;

Kumorotomo.Wahyudi, 2005. Akuntabilitas Birokrasi Publik Sketsa pada massa transisi. Jakarta. MAP UGM;

Kasim, Ashar, 1993. Pengukuran Efektivitas Dalam Organisasi. Jakarta. Pusat Sudi Antar Univcersitas Ilmu-Ilmu Sosial;

Listiani.Heny dan Sabarguna.Boy, Oganisasi Manajemen Rumah Sakit. Yogykarta. Korsorsium;

Islamy.Irfan, 2004. Prinsip Perumusan Kebijaksanaan Negara. Jakarta. Bumi Aksara;

Mazmanian, A, Daniel \& Sabatier, A, Paul, 1983. Implementation and Public Policy. London. Scott

Foresman and Company;

Michael, J, Ewen, 2003. The Foundations of Public Policy. Australia. La Trobe University;

Muninjaya. Gde, Manajemen Kesehatan. Yogyakarta. IKAPI;

Mustopadidjaja, 2003. Manajemen Proses Kebijakan Publik. Jakarta. LAN RI; 